\title{
Hem eller vårdplats - hur behandlas personer med omsorgsbehov i hyreslagstiftningen?
}

\author{
PER NORBERG
}

Genom ädelreformen 1992 fick kommunerna uppdrag att ordna särskilda boenden för personer med omsorgsbehov. Dessa boenden skulle utgöra den omsorgsbehövandes hem. De skulle betala hyra och därmed få de rättigheter som följer av hyreslagen. Artikeln beskriver hur denna grupp behandlats i domstolarna samt diskuterar ändamålsenligheten av att tillämpa hyreslagstiftningen på gruppen.

\section{Inledning}

För den som ligger i en sjukhussal är hemmet (som man ska återvända till när man blivit frisk) och vården skilda åt. Sjukhussalen är en kollektiv miljö där den enskilde måste ta hänsyn till sina grannar. Man kan inte köpa sig rätten till ett eget rum utan det ges bara till den vars sjukdom skapar störst behov. Den sortens vård

Per Norberg är Jur. dr. och lektor vid Juridiska fakulteten vid Lunds universitet. Forskningen är finansierad av Marianne och Marcus Wallenbergs stiftelse samt Ragnar Söderbergs stiftelse. är idag landstingens ansvar. I vården är alla människor lika och förmåner utgår i princip endast utifrån behovet. ${ }^{1}$

Före ädelreformen hade landstingen ansvar för boende på exempelvis sjukhem. Ofta organiserades det på samma sätt som sjukhusvård. Den som bäst behövde ett eget rum fick det och om behovet minskades kunde patienten flyttas till en annan form av vårdboende.

1 Att vården i praktiken ofta präglas av stora olikheter är ett känt problem, se exempelvis Brodin \& Mattsson i detta temanummer och (Silfverberg red. 2013). 
Hyreslagen (HL) är det vardagliga namnet på 12:e kapitlet Jordabalken (1970:994). I 1 § anges reglerna för när den lagen är tillämplig och det räcker med att en person hyr en del av ett hus (se vidare Holmqvist \& Thomsson 2013 s. 2-11). Den som hyr en rätt att använda en ledig P-ruta $i$ ett parkeringshus hyr en liten del av ett hus och hyreslagens regler om lokalhyra blir tillämplig (Nja 2001 s. 10). Den som är inneboende och hyr en rätt att använda en av två sängar i ett rum har förmodligen också ett hyresavtal (bostadshyra). Det viktiga är att när man väl ställt sig på rutan eller lagt sig i sängen så kan ingen köra bort en. ${ }^{2}$

När bostadshyra blandas med vård är det avgörande om bostaden (hemmet) bara är en underordnad del av avtalet (RBD 8:94 se också Bengtsson 2013 s. 15lff). När läkaren bestämde över rummet i långvården eller sängen i sjukhussalen var det självklart att hyreslagen inte gällde. Då var boendet ett underordnat moment $\mathrm{i}$ förhållande till vården/omsorgen. ${ }^{3}$ Samma sak gällde ofta för det boende som erbjöds andra personer med omsorgsbehov.

När hyreslagen inte gällde fanns det bara ett sätt att uppfatta situationen rättsligt, nämligen utifrån den samlade

2 Det minimum som krävs när man hyr en parkeringsruta är väl känt. Man kan hyra en icke specificerad plats. Det minimum som krävs på bostadsområdet är inte klarlagt men min bedömning är att en icke specificerad sovplats inom ett hus borde räcka även där. Det är trots allt fråga om social skyddslagstiftning.

3 Jfr RH 1999:10. Boendet som moment skulle bli åtskilligt starkare i detta rättsfall om en rätt att kvarstanna i rummet hade funnits. socialrättsliga lagstiftningen. Om den lagstiftningen gav en skyldighet att erbjuda en plats skulle kommun eller landsting ordna det. Rättsföljder som JO-anmälan och skadestånd kunde följa om det allmänna misslyckades.

Sedan början av 1990-talet har kommunerna fått huvudansvaret för icke medicinsk långvarig service, vård och omsorg för personer med omsorgsbehov. De skulle skapa särskilda boendeformer (servicelägenheter, vårdlägenheter, gruppboenden med mera). I första hand skulle en person med omsorgsbehov få hjälp i det vanliga hemmet. I andra hand skulle de kunna ansöka om särskilt boende och i tredje hand skulle de kunna läggas in på sjukhus eller annan institution (proposition 1990/91:14 s. 39). Det var inte bara en besparing. Så här sa man i propositionen:

Även den som är gammal eller handikappad har rätt till en bostad där friheten och integriteten är skyddad och där han kan få sina behov av stöd och hjälp i den dagliga livsföringen tillgodosedda... [Bostaden ska] rymma samtliga boendefunktioner och upplåtas på för bostadsmarknaden sedvanligt sätt (Proposition 1990/91:14, s. 39 och s. 42).

En följd blev att kommunerna slöt hyresavtal med den omsorgsbehövande. När lägenheterna skulle rymma samtliga boendefunktioner och upplåtas på sedvanligt sätt blev inte längre boendet ett underordnat element i förhållande till omsorgen och hyreslagen blev därmed tilllämplig. Numera finns två viktiga rättsliga regleringar nämligen: 
- Omsorgsgivare - omsorgsbehövande: Sociallagstiftningen gäller. Socialnämnden fattar beslut och förvaltningsrättsliga domstolar dömer.

- Hyresvärd - hyresgäst: Hyreslagen gäller. Hyresnämnder fattar beslut och civilrättsliga domstolar dömer.

Den här artikeln handlar enbart om den andra punkten, alltså om vad hyreslagen säger och hur domarna på det området ser ut. Därför redovisas ingen förvaltningsrättslig praxis från Högsta förvaltningsdomstolen eller dess föregångare Regeringsrätten.

Genom hela propositionen som föregick ädelreformen behandlas den omsorgsbehövande som en individ. Inte en enda gång tar man upp att individen kan ha en make/maka, ett eller flera barn och att bostaden kanske behöver vara funktionell för en hel familj. De problem som uppstår i och med att kommunens roll som hyresvärd ska åtskiljas från rollen som omsorgsgivare tas inte heller upp. Det gjordes inte en enda förändring av hyreslagen i syfte att få den att fungera för dessa människor. ${ }^{4}$

De problem jag tar upp i denna artikel är följande:

- Rätten att förändra lägenheten - En del av ädelreformen var att den omsorgsbehövande skulle få stöd utifrån sina egna

4 Man kan möjligen argumentera för att utsträckningen av rätten till andrahandsuthyrning 1998 i viss mån var riktad mot denna grupp. När kravet på viss tid togs bort blev det lättare för personer med omsorgsbehov att hyra ut lägenheter de inte kunde använda på flera år. (SFS 1998:146 och proposition 1997/98:46). önskemål. Var önskemålet att bo kvar i den gamla bostaden ska samhället ställa upp med bidrag för att anpassa den. Vad gäller om den egna bostaden är hyrd? Kan hyresvärden då säga 'Nej' till sådana anpassningar?

- Inrymmanderätten - En hyresgäst kan ha familjemedlemmar eller utomstående boende i lägenheten. Gäller det även för särskilda boenden?

- Övertaganderätten - Närstående som bor tillsammans med en hyresgäst har i vissa fall rätt att ta över hyreskontraktet. Gäller sådana rättigheter även i särskilda boenden?

- Bristande betalning - Hur fungerar de vanliga reglerna kring uppsägningar på grund av bristande (försenad eller utebliven) betalning för personer med omsorgsbehov?

- Störande beteende - Hur fungerar de vanliga reglerna kring uppsägningar av den som stör sina grannar när denne är en person med omsorgsbehov?

- Hyresregleringen - Hur fungerar den för särskilda boenden?

- Uppsägning i kombination med erbjudande om annat boende - Kan hyresgästen bli uppsagd och erbjudas ett annat boende för att någon annan behöver platsen bättre (exempelvis en person som fått ett biståndsbeslut)?

- Uppsägning i samband med nedläggning av särskilt boende - Vad krävs?

- Har den som flyttar in i ett särskilt boende rätt att behålla sin gamla lägenhet?

Dessa punkter kommer att behandlas i var sitt eget avsnitt. I den här delen tillämpar jag den vanliga rättvetenskapliga metoden 
(se exempelvis Lehrberg 2014 kap. 2.2.4.). Den innebär att man söker svaret i rättskällorna och den högsta rättskällan är lagtextens ordalydelse. ${ }^{5}$ Andra viktiga rättskällor är lagförarbeten, rättspraxis från högsta instans samt juridisk litteratur.

Alla rättsfall från de högsta instanserna som återfinns i databaser och behandlar rätten att få behålla ett särskilt boende efter ädelreformen finns med. Hyreslagen har två olika domstolssystem. I det ena går man från tingsrätt till hovrätt och vidare till Högsta domstolen. Den domstolen prövar bara mål där det finns ett starkt prejudikatvärde, det vill säga om det finns något viktigt att säga om hur lagen är tänkt att fungera. Det andra prövningssystemet består av hyresnämnden i första instans och Svea hovrätt (idag) samt Bostadsdomstolen (före 1 juli 1994) som andra och sista instans. Mål om uppsägningar av hyresgäster med besittningsskydd får alltid överklagas och måste tas upp av Svea hovrätt, det blir tusentals mål per år. De viktigaste målen sorteras ut som rättsfall från hovrätterna RH (cirka 200 rättsfall per år från alla civilrättens områden) eller rättsfall från Bostadsdomstolen RBD (drygt 20 rättsfall per år från de områden som före 1 juli 1994 kunde överklagas från hyresnämnder till Bostadsdomstolen).

På några områden kan man klart fastslå vad som är gällande rätt. Men på de flesta områden finns det inget säkert svar eftersom lagen innehåller avvägningsregler. I sådana fall görs en kort beskrivning av vad som gäller för vanliga hyresgäster och vad

5 Det gäller i de fall den rent nationella rätten inte påverkas av internationellt bindande rätt som EKMR eller EU-rätten. domstolarna skulle kunna väga in i sina bedömningar av särskilda boenden.

Jag avslutar med en diskussion kring hur man ska se på de svar som ges i rättspraxis, men även de svar som inte ges. Är det lämpligt att låta hyreslagen vara tillämplig i dessa fall eller borde den i förändras eller kanske ersättas med annan lag?

\section{Rätten att anpassa lägenheten så att fortsatt boende blir möjligt}

Rätten att förändra lägenheten infördes i mitten av 1970-talet som 24 a $§$ i hyreslagen (SFS 1974:820 och proposition 1974:150). Där sägs att bostadshyresgäster har rätt att på egen bekostnad utföra målning, tapetsering och därmed jämförliga åtgärder (för exempel på jämförliga åtgärder se proposition 1974:150, s. 457 och s. 489). Hyresgästen får inte ändra i lägenhetens planlösning eller göra någon anpassning av husets gemensamma delar. Där gäller hyresvärdens äganderätt.

Det första steget när en person får omsorgsbehov är ofta att erbjuda stöd i det hem som denne har. Det finns bidrag att söka för att anpassa boendet. Den som äger sin bostad genomför den åtgärd personen fått bidrag för. ${ }^{6}$ Men så lätt är det

6 När det gäller bostadsrätter krävs styrelsens tillstånd för väsentliga förändringar och ett sådant tillstånd ska ges om inte ombyggnaden skadar huset (Bostadsrättslag 1991:614 7 kap. 7 §). Detta är specialreglerat för att bostadsrätten inte alltid har varit en äganderätt. Tidigare har såväl den principiella rätten att ändra lägenheten samt rätten att sälja den till högstbjudande saknats. För övriga äganderätter är rätten att förändra det man äger en så självklar del att den inte lagreglerats. 
inte för en hyresgäst. Skulle hyresgästen till exempel behöva en dörröppnare på husets entré kan hyresgästen ansöka och få bidrag både för öppnaren och för att sedan ta bort den om den behövande hyresgästen flyttar eller dör (se lag 1992:1574 om bostadsanpassningsbidrag 2 §). Ändå kan hyresvärden vägra att tillåta att dörröppnaren installeras. De gemensamma delarna av huset bestämmer hyresvärden över och det finns ingen allmän lagregel som kan användas för att tvinga en hyresvärd att tillgodose en hyresgästs omsorgsbehov. ${ }^{7}$

Inuti lägenheten kan hyresgästen till exempel sätta upp ett handtag som gör det lättare att komma i och ur badkaret, ${ }^{8}$

7 Även om en allmän regel saknas så kan det finnas speciella regleringar som en kommun kan använda. Om hyresvärden behöver bygglov kan man i förhandlingar komma överens om att det blir Nej till att bygga nya hus om inte hyresvärden går med på anpassning av lägenheten eller gemensamma utrymmen för en person med omsorgsbehov i ett gammalt hus. Om det t.ex. finns en tandläkarmottagning i samma trappuppgång som den omsorgsbehövande kan man kräva en dörröppnare och en ramp enligt tillgänglighetslagstiftningen. Tandläkarmottagningen är en plats dit allmänheten ska ha tillträde och då kan en hyresvärd vara skyldig att åtgärda enkelt avhjälpta hinder. Men den lagstiftningen gäller inte hyreshus med enbart privatbostäder. Sådana hus är inte en plats som allmänheten ska ha tillgång till (jfr 2 \& i Boverkets författning BFS 2003:19).

8 Att sätta upp kakel nämns som ett exempel på vad som får göras i proposition 1974:150 (s. 457) och uppsättning av ett handtag är ett likvärdigt ingrepp. Trots att kakeluppsättning kan leda till fuktproblem är den övervägande uppfattningen i litteraturen att hyresgästen fortfarande får göra det, (se Edling 2014 s. men hyresgästen kan inte ändra lägenhetens planlösning och t.ex. bredda en hall eller göra badrummet större på ett annat rums bekostnad. ${ }^{9}$ När det gäller den vanliga hyresgästens behov av att få uttrycka sin personlighet genom att ändra lägenhetens ytskikt ger alltså 24 a $\S$ HL en tydlig rätt som kan användas mot den lilla minoritet av hyresvärdar som själva vill bestämma helt och hållet över lägenheten. Vad gäller åtgärder för att anpassa lägenheten till en hyresgäst med omsorgsbehov finns ingen liknande reglering. ${ }^{10}$ Bara det som råkar falla innanför $24 \mathrm{a} \S \mathrm{HL}$ tillåts. I övriga fall får hyresvärden säga 'Nej' hur svaga skäl denne än har. Hyresvärdens principiella äganderätt ges företräde framför hyresgästens intressen.

När ädelreformen genomfördes betonades rätten för de äldre och andra med omsorgsbehov att välja boendeform och bo kvar i den form de valt även om de gradvis blir allt sämre. Men den rätten gäller bara i förhållande till kommunen/

179f.) se också P Björkdahl (2013 s. 138) som menar att en rimlig riktlinje är att arbetet utförs av en fackman.

9 Edling (2014), s. 180, se också proposition 1974:150, s. 489. Dessa exempel är uppenbart otillåtna eftersom lägenhetens planlösning ändras.

10 Även om omsorgsbehovet också utgör en funktionsnedsättning i diskrimineringslagens mening så kan den lagen ändå inte användas eftersom det på området varor, tjänster och bostäder inte finns något självständigt krav på skäliga anpassningsåtgärder. Den lagförändring där bristande tillgänglighet blir en ny form av direkt diskriminering från 1 januari 2015 ändrar inte på detta, framförallt för att bostadsområdet är undantaget i nya $2 \mathrm{kap} .12 \mathrm{C}$ $\S D L, S F S$ 2114:958, proposition 2103/14:198. 
samhället som omsorgsgivare/bidragsgivare. Den gäller inte gentemot hyresvärden. I en sådan här fråga kan man vara helt säker på rättsläget. Hyresvärden äger huset. Utan lagstöd kan en domstol inte ge hyresgästen rätt att anpassa lägenhetens planlösning eller ett allmänt utrymme till hyresgästens omsorgsbehov. Det spelar ingen roll vad de socialrättsliga lagarna säger. De lagarna innefattar bara skyldigheter för omsorgsgivare som kommuner och kan inte ge skyldigheter för en privat hyresvärd.

Det kan tyckas märkligt att man i samband med ädelreformen inte ändrade $\mathrm{i}$ hyreslagen så att hyresvärden blev skyldig att acceptera anpassning av lägenheter och gemensamma utrymmen till hyresgäster med omsorgsbehov.

\section{Kan man inrymma utomstående i särskilda boenden?}

En viktig rättighet som fanns redan i 1907-års hyreslag är inrymmanderätten i $41 \S$ HL. Den vanliga hyresgästen har rätt att inrymma utomstående om hyresvärden inte lider men (skada) av det. Någon sådan skada för hyresvärden kan knappast uppstå om två personer bor i en normalstor komplett enrumslägenhet. Den rätten används både av den som vill låta sin sambo/maka flytta in och av den som vill dela en lägenhet med en kompis för att få råd med hyran.

När regeln fanns i tidigare jordabalk ${ }^{11}$ (före 1970) användes ordet främmande

11 Lag 14 juni 1907 om nyttjanderätt till fast egendom 3 kap 23 § 2 st (så som regeln såg ut 1969). istället för ordet utomstående. Ordet främmande visar att den ursprungliga avsikten när regeln skapades $1907^{12}$ var att familjemedlemmar som ingår i hyresgästens hushåll alltid skulle få vara inneboende. ${ }^{13}$

Jag menar dock att det är orimligt att tro att regeln fortfarande har samma innebörd. I juridiken är lagtextens ordalydelse den högsta rättskällan. Om lagtexten direkt sagt ut att en hyresgäst alltid har rätt att ha familjemedlemmar som inneboende så hade det gällt. Då hade den som bara hyrt ett rum som inneboende hos en privatperson kunnat dela det med sin make/maka samt sina barn, men nu säger lagtexten inte det.

Lagtexten säger att man inte får hyra ut till utomstående om det kan leda till men för hyresvärden. Motsatsvis kan man då tolka det så att man alltid har rätt att hyra ut till utomstående om hyresvärden inte lider men. Den motsatstolkningen är okontroversiell och anses bindande enligt $1 \S 5$ st. HL (se exempelvis Holm-

12 Lag 14 juni 1907 om nyttjanderätt till fast egendom 3 kap $23 \S 1$ st. 3 p (så som regeln såg ut 1907).

13 Den inneboenderätten balanserades dock av att hyresvärden var fri att säga upp hyresgästen om denne ogillade de inneboende. Skyddet i dåvarande 3 kap 23 § 1 st. 3 p. gällde bara mot uppsägning i förtid - det fanns inget skydd mot uppsägning med korrekt uppsägningstid. Ordet främmande är så entydigt $\mathrm{i}$ förhållande till familjemedlem som ingår $i$ hyresgästens hushåll att rätten att inrymma dem aldrig prövades. Det som prövades var gränsen mellan inrymmande (när hyresgästen bor kvar) och överlåtelse (när hyresgästen lämnat lägenheten). Se Lejman (1951 s. 90ff). 
qvist \& Thomsson 2013 s. 340). Med det menas att hyresvärden och hyresgästen inte kan avtala bort rätten att ha inneboende.

En regel som säger att man alltid får ha familjemedlemmar som inneboende oavsett hur stora men det leder till för hyresvärden är emellertid enligt min mening idag en övertolkning. En student som hyr ett studentrum och låter fru och barn flytta in i det skulle med största sannolikhet bli uppsagd. Övriga boende (och därmed hyresvärden) skulle lida så stora men att det skulle kunna leda till en uppsägning.

En motsatstolkning av en lagtext har en betydligt svagare rättslig ställning än en lagregel som fastställer något direkt. Det finns inga moderna rättsfall som avgör saken. Lagtexten har idag en annan ordalydelse än 1907 och vi lever i en annan tid.

För en äldre människa med omsorgsbehov och ett särskilt boende är maken/ partnern det man först tänker på. Man kan också tänka sig att ett barn eller barnbarn eller en vän blivit bostadslös och att hyresgästen vill hjälpa till genom att ordna en sovplats. Den rättsliga frågan blir på vilket sätt rekvisitet - men för hyresvärden - ska tolkas. En annan fråga är om rättspraxis ska göra skillnad på om det är livskamraten sedan 50 år som ska inrymmas eller någon mera avlägsen släkting eller vän.

Om en människa - gammal eller ung - i ett särskilt boende vill hyra ut till en vän och denne lagar sin mat i lägenheten, och undviker att använda de gemensamma utrymmena, kan det vara svårt att hävda att hyresvärden lider men. Även om den inneboende använder de gemensamma utrym- mena så är det något som man kan argumentera för att hyresvärden måste tåla.

I november 2012 kom en lagändring som gav kommunerna skyldighet att låta friska makar/sambor följa med sjuka äldre till särskilda boenden (socialtjänstlagen 4 kap 1 § b ändrad genom SFS 2012:597). En förutsättning är dock att deras sammanboende anses varaktigt. En sådan lagregel kan utgöra ett starkt skäl för en domstol att lägga särskild vikt vid denna grupp av inneboenden och att då låta hyresvärden acceptera större men från dem än från andra inneboende. Den nya regeln i socialtjänstlagen bygger på ett nationellt värdegrundsarbete (proposition 2011/12:147 s. 9ff) och alla myndigheter måste rimligtvis ta hänsyn till nationens gemensamma värdegrunder.

Den stora skillnaden mot exemplet med anpassning av lägenheten är alltså att $41 \S \mathrm{HL}$ erbjuder stora möjligheter till tolkningsutrymme. De myndigheter som tillämpar hyreslagen tar hänsyn till sociallagstiftningen och nationella värdegrunder om hyreslagen ger dem ett tolkningsutrymme som tillåter det. Tolkningsutrymmet i 41 § HL uppstår av två skäl. Det första skälet är att motsatsslut aldrig är lika bindande som entydig direkt lagtext och det andra skälet är alltså att ett nyckelbegrepp "men" är av en sådan karaktär att det alltid föreligger i högre eller mindre grad. Varje boende sliter åtminstone lite på lägenheten. Den verkliga frågan blir om menen är så stora att man ska låta hyresvärdens intresse väga över. Här finns det alltså inte några rättsfall som kan tjäna som vägledning. 


\section{Finns en övertaganderätt även avseende särskilda boenden?}

Det finns ett principiellt överlåtelseförbud i $32 \S H L$. En hyresgäst som inte längre vill bo kvar i lägenheten får inte lämna över den till någon annan person. Men förbudet är försett med en mängd undantag. Den som tilldelas en hyreslägenhet genom bodelning har enligt $33 \S \mathrm{HL}$ en absolut rätt att ta över hyreskontraktet. Man gör ingen prövning av den nye hyresgästen utan övergången av kontraktet sker automatiskt (RBD 23:90). Det enda som krävs är att lägenheten varit avsedd att användas som gemensam bostad eller har använts som gemensam bostad (jämför Ryrstedt 1998 s.185f).

Sätter man ihop 41 § med 33 § hyreslagen kan alltså en person med biståndsbeslut som erbjuds ett särskilt boende tacka 'Ja' till lägenheten. När denne väl fått ett kontrakt med omsorg och boende kan livskamraten, ett barn eller en vän flytta in. Avlider hyresgästen och det är maken, makan eller sambon som fått lägenheten genom bodelning finns det inget hinder mot att den fullt friske därmed blir ensamstående i lägenheten. ${ }^{14}$ Vill hyresvärden göra sig av med hyresgästen måste

14 Det är inte fullt klart hur rekvisitet införskaffats för gemensamt bruk skall tolkas i denna situation men min uppfattning är att om ett par ansöker om ett särskilt boende på grund av den ena partnerns omsorgsbehov och har för avsikt att bo i lägenheten tillsammans genom att använda sig av $41 \S \mathrm{HL}$ så är den bostaden inskaffad för gemensamt bruk och ingår i bodelningen. det ske genom en uppsägning enligt 46 $\S$ HL och 49 § HL. Sociallagstiftningen (exempelvis att det kan finnas en annan person som har ett biståndsbeslut på att denne behöver den särskilda bostaden) omformas då till skälet till att hyresvärden vill säga upp den hyresgäst som saknar biståndsbeslut. Men det är hyresnämnden och Svea hovrätt som enligt hyreslagens regler avgör om det skälet väger tyngre än hyresgästens hemskydd.

Vill andra närstående göra ett övertagande gäller 34 § HL och då blir det betydligt svårare eftersom man bland annat ska ta hänsyn om hyresvärden skäligen kan nöja sig med den nya hyresgästen (sociallagstiftningen blir då det skäl som gör att hyresvärden kanske inte måste nöja sig med en hyresgäst som inte har ett biståndsbeslut) och om det är en vän eller annan utomstående som flyttat in finns ingen övertaganderätt alls.

Hyresrättsligt gäller alltså att den som är gift eller sambo ${ }^{15}$ automatiskt får starka rättigheter mot sin hyresvärd om partnern avlider eller om paret separerar och lägenheten $\mathrm{i}$ bodelningen placeras hos en annan än den som stod på kontraktet. Även om lägenheten inte skulle ingå i en bodelning så ger 47 §och $33 \S \mathrm{HL}$ i fören-

\footnotetext{
15 Ryrstedt visar i sitt bidrag i detta temanummer hur besvärligt sammanboendebegreppet kan vara för personer som drabbats av demens. Hennes slutsats är att troligen kan även en svårt dement person ingå ett nytt sammanboende. Svårigheterna ligger i att bedöma frågan om vilka kognitiva färdigheter som krävs för att ingå ett samboförhållande enligt familjerättens reglering.
} 
ing med $22 \S$ sambolagen, en efterlevande sambo betydelsefulla rättigheter om lägenheten använts för gemensamt bruk.

Även på detta område saknas rättsfall om särskilda boenden. Antingen tillåter kommunerna sådana övertaganden eller så accepterar de som vägras överta ett särskilt boende kommunens beslut.

\section{Är bristande betalning en uppsägningsgrund även för den som fått ett särskilt boende?}

Det finns två sätt för en hyresvärd att göra uppsägningar:

- Uppsägning då hyresgästen ska flytta ut omedelbart som kan prövas av tingsrätten i första instans.

- Uppsägning med uppsägningstid (minst 3 månader) och som måste godkännas av hyresnämnden.

Hyreslagstiftningen är mycket hård vid hyresskulder. Sköter hyresvärden det formella rätt har hyresgästen tre veckor på sig att betala och socialnämnden har tre veckor på sig att påta sig betalningsansvaret för lägenheten. ${ }^{16}$ Sker inte något av dessa två saker är hyresrätten förverkad enligt 42-44 §§ HL och om hyresvärden genomför en uppsägning i förtid ska hyresgästen lämna lägenheten.

Kan hyresvärden bevisa att alla meddelande som ska skickas har skickats är det upp till hyresgästen/socialnämnden att bevisa att skulden blivit betald i rätt tid

16 En översikt over de formella kraven ges i Grauers (2014 s. 55-58). eller att socialnämnden påtagit sig betalningsansvaret i rätt tid. Misslyckas de med detta vinner hyresvärden. I Sverige vräks även barn för små hyresskulder hos föräldrarna, i $80 \%$ av de fallen understiger hyresskulden 20.000 kronor (Stenberg, Kjellbom, Borg \& Sonmark 2011 s. 5).

En hyresvärd som skött allt det formella rätt enligt 42-44 $\S$ HL kan välja mellan en uppsägning för omedelbar avflyttning (förtid - som i så fall prövas av tingsrätten) eller en uppsägning med tre månaders uppsägningstid som prövas av hyresnämnden. Även om alla formkrav i $42-44$ § inte är uppfyllda så kan en hyresvärd be en hyresnämnd godkänna en uppsägning på grund av upprepade hyresförseningar enligt $46 \S 2$ p. HL. I de fallen blir det en mera allmän avvägning av hyresgästens intresse av att bo kvar i lägenheten och hyresvärdens intresse av att avsluta hyresförhållandet.

\section{SÖH $4945-10^{17}$}

I detta fall hade den privata hyresvärden åberopat just $46 \S 2$ p. HL. En 85-årig kvinna som hade bott 69 år i lägenheten och led av "åldersglömska", hade inte betalat hyran. År 2005 hade hon blivit uppsagd men då betalade socialnämnden hennes hyresskuld och garanterade hyran för ett år framåt. Hyresvärden avbröt därför uppsägningsförfarandet. Socialnämnden valde sedan att sluta betala hennes hyra och hon fick själv tillgång till hela sin pension. År

17 SÖH står för Svea hovrätt överklagade hyresmål. Det är rättsfall som ibland finns tillgängliga i databaser men som inte har samma höga värde som $\mathrm{RH}$ och RBD-fall eftersom SÖHfallen inte är utvalda som särskilt viktiga. 
2010 när målet kom till hyresnämnden nästa gång hade hon en hyresskuld motsvarande sex månadshyror (27.300 kronor). Socialnämnden hade gett henne 23.000 kronor för att reglera hyresskulden. Men dessa pengar hade på något sätt försvunnit. Socialnämnden ville inte betala en gång till för samma hyresskuld.

Kvinnans advokat hade ansökt om förvaltare för att säkerställa att framtida hyror skulle betalas punktligt. Något sådant beslut hade dock inte fattats då hyresnämnden prövade frågan i maj 2010. I oktober 2010 avgjorde Svea hovrätt överklagandet. Hyresskulden skulle betalas av socialnämnden om kvinnan fick behålla sin lägenhet. Kvinnan hade då också fått en förvaltare utsedd som skulle komma att betala hyran punktligt framöver. Ändå förlorade hon sin lägenhet $i$ båda instanserna. Man vet inte vad som hände med henne sedan. Hon kan ha blivit bostadslös. Hon fick knappt fyra veckors uppskov med avflyttningen men det var allt.

Det tragiska i detta mål är att om hela hyresskulden varit reglerad och om förvaltare hade hunnit utses redan när hyresnämnden prövade målet i maj 2010 hade kvinnan med största sannolikhet fått behålla sin lägenhet. ${ }^{18}$ Hennes situation

18 Det hade nog räckt att hyresskulden betalats innan Svea hovrätt prövade målet. Se Holmqvist \& Thomson (2013 s. 441f). Några opublicerade rättsfall tolkar författarna så att Svea hovrätt i princip inte accepterar att sociala myndigheter villkorar en betalning av en hyresskuld av att hyresvärden går med på en förlängning. Min uppfattning är att det var för att socialnämnden bröt mot den regeln som utrymme inte fanns att ta hänsyn till hyresgästens starka sociala skäl. måste rimligtvis vara ganska vanlig idag. En demens som sakta blir allt svårare bör typiskt sett yttra sig i just misskötsamhet med betalningar. Det var socialnämnden som agerade bristfälligt. Ingen där insåg att hon inte klarade av att hantera sin ekonomi själv, utan man behandlade henne som en misskötsam person som skulle få stå sitt kast. Dessutom förstod socialnämnden nog inte vikten av att hyresskulden betalades. ${ }^{19}$

\section{Kan den som fått ett särskilt boende bli uppsagd på grund av störande beteende?}

Det finns två sätt för en hyresvärd att göra uppsägningar:

- Uppsägning då hyresgästen ska flytta ut omedelbart och som kan prövas av tingsrätten i första instans.

- Uppsägning med uppsägningstid (minst 3 månader) och som måste godkännas av hyresnämnden.

Formen är alltså densamma vid störningar som vid bristande betalning. Vid särskilt allvarliga störningar (exempelvis om hyresgästen misshandlat en granne ${ }^{20}$ går man direkt till uppsägning. Allt hyresvärden behöver göra är att meddela socialnämnden om att hyresgästen kommer att bli bostadslös. Hyresgästen blir då uppsagd utan att få någon uppsägningstid. I övriga fall får dock en uppsägning inte

19 Se not 18 ovan.

20 Se t.ex. NJA 2008, s. 243 och RH 2006:72. 
ske utan att hyresvärden först anmodat hyresgästen om rättelse och underrättat socialnämnden. ${ }^{21}$ Syftet med de bestämmelserna är att ge hyresgästen en chans att bättra sig och att ge socialnämnden en chans att erbjuda det stöd som kan krävas för att komma tillrätta med störningarna (proposition 1992/93:115, s. 20).

Liksom vid hyresförseningar kan en hyresvärd som skött allt det formella på ett korrekt sätt välja mellan en uppsägning för omedelbar avflyttning (som i så fall kan prövas av tingsrätten) eller en uppsägning med tre månaders uppsägningstid som prövas av hyresnämnden. Även om alla formkrav i 42-43 $\S$ inte är uppfyllda kan en hyresvärd be en hyresnämnd godkänna en uppsägning på grund av upprepade störningar enligt $46 \S 2$ p. HL. I de fallen blir det en mera allmän avvägning av hyresgästens intresse av att bo kvar i lägenheten och hyresvärdens (i praktiken grannarnas) intresse av att avsluta hyresförhållandet (se exempelvis Larsson, Synnergren \& Wahlström 2014 s. 207f). Det finns gott om fall rörande vanliga hyreslägenheter men såvitt jag kunnat se bara ett fall rörande särskilda bostäder.

\section{SÖH8124/09}

Fallet gällde ett serviceboende med 15 servicelägenheter, 7 vårdbostäder och 7 seniorlägenheter, vidare fanns sex vanliga lägenheter men de låg i en särskild bygg-

21 Hyreslagen $42 \S 1$ p. 6 stycket och $42 \S 3$ st. nad och omfattades inte av tvisten. En hyresgäst störde sina grannar genom att kontrollera dem. Hon satte sig på en stol just utanför deras altaner och tittade in $\mathrm{i}$ deras lägenheter, hon följde med dem när de skulle gå till tvättstugan med mera. Vid ett tillfälle gick hon in i en lägenhet genom en öppen altandörr när hyresgästen sov. Vid ett annat tillfälle lyckades hon få komma in i en annan hyresgästs kök för att kontrollera att denne inte använt spisen för bakning (det skulle ha kunnat påverka hennes elallergi). Hon anklagade sina grannar för att ha inneboende, festa sent på kvällarna, ha apparater som spred strålning som hon var allergisk mot, att bespruta hennes lägenhet med kemikalier med mera.

I rättsfallet tog hyresvärden upp att det var ett serviceboende och ville att det skulle medföra att övriga hyresgästers trygghet skulle ges extra vikt. ${ }^{22}$ Hyresnämndens beslut följer dock helt vad som gäller för vanliga hyresgäster. Det handlar om vilka störningar som faktiskt ägt rum, vilka varningar som hyresvärden gett hyresgästen samt hur en vanlig fullt frisk hyresgäst skulle uppfatta dessa störningar. Hyresvärden vann och uppsägningen godkändes i hyresnämnden och efter ett överklagande även av Svea hovrätt.

22 Samma fråga behandlas av Peterson-Björkdahl (2004/05 s. 260). Såväl de hyresgäster som blir störda som den hyresgäst som stör är ofta extra skyddsvärda. Hennes slutsats är att bedömningen som huvudregel inte bör påverkas av att den störande är funktionshindrad. 


\section{Hur tillämpas hyresregleringen i särskilda boenden?}

Bruksvärdesprincipen är namnet på den hyresreglering som nu gäller. Den infördes mellan 1968 och 1974 och innebär att hyran skall sättas utifrån vilket värde lägenheten har för den genomsnittlige brukaren utan hänsyn till hyresvärdens kostnader (jfr Edling 2014 s. 380 och s. 382.). Från början skulle man främst (bara) jämföra med kommunala (allmännyttiga) lägenheter. Men från år 2011 ska man jämföra med lägenheter som fått sin hyra bestämd i kollektiva förhandlingsöverenskommelser (där Hyresgästföreningen oftast är hyresvärdens motpart) oavsett om huset ägs av privata hyresvärdar eller av ett allmännyttigt bostadsföretag. ${ }^{23}$

Det finns en grupp rena hyresregleringsmål som avser särskilda bostäder. ${ }^{24}$ I de fallen gör hyresnämnden och Svea hovrätt alltid sitt bästa för att fastställa hur hög bruksvärdeshyran skulle ha varit om lägenheten inte varit en del av ett omsorgs- och boendepaket. Sedan gör man ett skäligt tillägg för värdet av service. I RH 1997:93 ville kommunen höja hyran med $3 \%$, det innebar att de boende i servicelägenheterna skulle betala mellan 3.300 och 4.500 kronor per månad för sina lägenheter. Dessutom utgick en serviceavgift på 618 kronor per månad. Den avgiften var obligatorisk och gav tillgång till sjuk-

23 SFS 2010:811.

24 Se t.ex. RBD 8:94 SÖH 47/95, SÖH 75-76/95, SÖH 3946/07, SÖH 2385/09, SÖH 2750/09, SÖH 10010-10,SÖH 4763/13. sköterska dygnet runt, tillgång till arbetsterapeut och sjukgymnast, samt larm med tillgång till personal dygnet runt. Hyresnämnden och Svea hovrätt underkände hyreshöjningen. Det avgörande var att bruksvärdeshyran understeg summan av hyra och obligatorisk avgift.

Det är en stark princip i hyresregleringen att det är lägenheten som hyressätts - inte hyresgästen (se till exempel hyresförhandlingslagen (1978:304) 5 §). Ingår exempelvis en parkeringsplats ska hyran ändå vara lika stor oavsett om hyresgästen har bil eller ej. ${ }^{25}$ Vill man ta extra betalt av dem som använder parkeringsplatserna måste parkeringsavtalen vara frivilliga. På samma sätt är det med omsorgsavgifter. Är de obligatoriska ingår de i hyran och värderas formellt sett utifrån vad en tänkt genomsnittlig hyresgäst har för nytta av dem (man gör i praktiken en skäligt tillägg). Endast om hyresgästen har rätt att avstå från omsorgsförmånen och då slippa avgiften, faller den utanför hyresregleringen.

Idén om värdet för den genomsnittlige hyresgästen syns också i värderingen av gemensamma utrymmen. Ett gemensamt kök som hyresgästen bara kan utnyttja i samband med måltider denne betalar för, är exempelvis mindre värt än ett gemensamt kök där man kan bjuda in sina kamrater för att baka tillsammans eller sitta och dricka en kopp kaffe tillsammans, såsom fallet brukar vara i ett studentboende(RH 1996:107).

25 Bengtsson \& Hager \& Victorin (2013 s. 98). Med hänvisning till RBD 9:88 (kabel-TV räknas lika oavsett om hyresgästen uppskattar det eller ej). 
I hyresregleringsmål kan det också komma upp argument som relaterar till principiella frågor om likhet och olikhet mellan särskilda boendeformer och andra lägenheter. I SÖH 1114-10 ville hyresgästen ha en stor hyressänkning eftersom hon skämdes över att bo på ett gruppboende för personer med funktionsnedsättning. Hon menade också att personer med kognitiva funktionsnedsättningar oftare utsatte varandra för störningar och hot än andra hyresgäster och att det skulle vara ett skäl att sänka hyran. Såväl hyresnämnden som Svea hovrätt underkände det argumentet. Det enda som var relevant var vad en grupp friska personer som fått hyra de sju lägenheterna skulle ha ansett om lägenheternas bruksvärde, plus ett skäligt tillägg för värdet av den omsorg som ingick i hyran.

I SÖH 774/07 hade sex boende på samma gruppboende begärt sänkt hyra. Endast i ett av fallen var hyran för hög och hyresnämnden sänkte den. Just den boende ansåg hyresnämnden ha en sämre lägenhet än övriga boende och den lägenheten kunde inte prissättas efter samma norm som de andra lägenheterna. Det ärendet överklagade kommunen/hyresvärden till Svea hovrätt och förlorade.

\section{Kan en hyresgäst sägas upp från ett särskilt boende för att någon annan (enligt ett omsorgsbeslut) behöver lägenheten bättre?}

RBD 8:94 var det första rättsfallet där de nya principerna med ädelreformen skulle prövas hyresrättsligt. De två hyresgästerna bodde i var sitt rum i ett gammalt ålderdomshem på 15 respektive $20 \mathrm{kvm}$ och med toalett. En av de två viktigaste saker som sägs i detta rättsfall handlar om just uppsägning av en person med mindre behov för att istället ge lägenheten till en person med större behov trots att rättsfallet i formell mening är ett rättsfall om hyresreglering.

Kommunen ville höja hyran och de båda hyresgästerna (genom sina anhöriga) motsatte sig hyreshöjningen. Frågan i hyresnämnden blev om hyresnämnden skulle fatta ett hyresregleringsbeslut baserat på vad deras boende var värt för den genomsnittlige hyresgästen såsom $55 \S$ hyreslagen föreskriver. Hyresnämnden kom fram till att det var principiellt fel att tillämpa hyreslagens regler på boendet.

J och E har vissa egna möbler i sina rum. Ingsbergsgården med dess korridorer och gemensamma utrymmen såsom matrum, pentry, dagrum, större duschrum, samt i övrigt även personalrum, några behandlingsrum, samtliga med kommunens inredning är huvudsakligen av institutionskaraktär. Sådan karaktär präglar alltjämt de besiktigade rummen och utrymmena. De normala dragen för en bostadslägenhet saknas således (RBD 8:94, s. 37).

Eftersom hyresnämnden inte ansåg att detta var en bostad utan en institution avvisades målet. Tvisten gällde egentligen bara hyran. Kommunen presenterade emellertid stora delar av avtalskonstruktionen för att understryka att man hade med villkor som var ogiltiga eller åtminstone tveksamma i ett hyresavtal och att 
det därför inte kunde röra sig om bostadshyra. Följande villkor lyftes fram:

1. Hyresgästen vet om att Nässjö kommun inte kan ge hyresgästen rätt att byta eller låta annan överta lägenheten. Detta beror på att behovet avgör vilka som får hyra dessa servicelägenheter.

2. Hyresgästen ska samtidigt som hyran betalas också inbetala särskild serviceavgift som fastställs av socialnämnden.

3. Personal inom hemtjänsten har rätt att med egen nyckel ta sig in i lägenheten om trygghetslarmet utlöses.

4. I de fall makar flyttar in i ett vårdboende och den ena maken går bort, kommer vårdbehovet för den kvarvarande maken att prövas. Det kan innebära att den kvarvarande maken hänvisas till ett annat boende.

Kommunen lyfte också fram att det för hyresgästerna/omsorgstagarna ibland var bra att hyreslagens regler inte gällde. Exempelvis skulle kommunen ha haft rätt att säga upp störande hyresgäster om störningarna blivit så allvarliga att en förverkandegrund förelåg.

Bostadsdomstolen ändrade hyresnämndens beslut. Man slog fast att ädelreformen innebar att kommunerna fick i uppgift att ordna särskilda boenden för personer med omsorgsbehov. I ett särskilt boende var det viktigt att hyresgästens hem skyddades. Därför var det viktigt att hyran inte kunde höjas hur som helst. Målet återförvisades till hyresnämnden som fick fastställa skälig hyra.

I juridiken gör domstolar ibland uttalanden som kallas obiter dictum (det i övrigt sagda). Det är när domstolen för ett principiellt resonemang om något som inte behövs för att avgöra målet. Här förde domstolen ett obiter dictum om övriga delar av hyresvillkoren i Nässjö kommun.

Kommunen kan vidare inte säga upp avtalen utan att det föreligger en upphörandegrund enligt samma kapitel. $\mathrm{J}$ och E kan alltså inte utan en sådan grund tvingas flytta från sina rum till andra rum. /... Att kommunen har det yttersta ansvaret för hyresgästerna som vårdtagare kan, enligt Bostadsdomstolens mening, inte hindra att hyresavtalen kan bringas att upphöra om hyresgäster t.ex. underlåter att betala hyran eller $\mathrm{i}$ annat fall allvarligt åsidosätter sina förpliktelser. /.../ Den omständigheten att flera av bestämmelserna i 12 kapitlet jordabalken saknar tillämpning i detta fall på grund av lägenheternas art och de särskilda villkoren för upplåtelserna utesluter inte att upplåtelserna anses som hyra (RBD 8:94, s. 41).

Bostadsdomstolen behövde alltså bara svara på frågan om hyresregleringen gällde eller inte, men valde att svara på fler frågor. Det intressantaste svaret gällde denna klausul:

4 I de fall makar flyttar in i ett vårdboende och den ena maken går bort, kommer vårdbehovet för den kvarvarande maken att prövas. Det kan innebära att den kvarvarande maken hänvisas till ett annat boende. 
Bostadsdomstolen signalerade att en sådan klausul inte självklart kunde upprätthållas. Gången vid ett dödsfall är att man börjar med en bodelning. Vid bodelningen kommer den efterlevande att få bostaden på sin lott om de är gifta eller sambo och lägenheten införskaffats för gemensamt bruk. ${ }^{26}$ Enligt $33 \S$ hyreslagen har de automatiskt rätt till ett hyreskontrakt med värden. Det finns ingen möjlighet alls för kommunen/hyresvärden att stoppa detta. Det man kan göra är att säga upp den nya hyresgästen men det kräver saklig grund enligt 49 § i förening med $46 \S$ i hyreslagen.

Den avgörande bestämmelsen blir tionde punkten i $46 \S$ HL som säger att uppsägningen ska godkännas om den inte strider mot god sed på hyresmarknaden eller eljest är oskälig mot hyresgästen. Det är en avvägningsregel. Är livskamraten ung och frisk vill denne förmodligen flytta till annat boende. Men om livskamraten är äldre kan denne trivas på hemmet, denne kan ha skaffat vänner där med mera. Även om det finns en person i kön som behöver lägenheten bättre (och har ett biståndsbeslut) så kan det vara oskäligt att flytta livskamraten (som saknar biståndsbeslut) till ett annat boende. Det är hyresnämnden och Svea hovrätt som med hjälp av hyreslagen ska

26 Även om lägenheten inte införskaffats för gemensamt bruk så finns det en möjlighet för sambo att få överta den enligt 22 § Sambolagen (2003:376) i förening med 33 § HL. Om samboförhållandet är barnlöst är det dock mycket svårt att få överta en lägenhet. Se vidare Ryrstedt (1998 kap. 13.5.3). avgöra hur den ena personens hemrätt ska vägas mot en annan persons omsorgsbehov - inte kommunen själv med stöd av socialtjänstlagen, LSS eller någon annan lag som kan ge rätt till bistånd.

Avvägningen mellan hemskydd och omsorgsbehov kan se ut på många sätt. En person som är förvirrad och som kan lida skada om denne avviker från boendet kan behöva boende på en avdelning där personaltäthet och olika låssystem förhindrar att personen ger sig av utan att personalen får kunskap om det. Om personen blir sämre och bara kan röra sig med hjälp av personal kan denne kanske flyttas till en mindre "säker" avdelning. Men det betyder nya grannar och ett nytt hem. Ska de anhöriga, en god man eller en förvaltare kunna hävda i hyresnämnden att den förvirrade upplever sitt rum som ett hem på samma sätt som andra gör? Ska den som inte längre kan röra sig få uppehålla en dyr plats på en avdelning med högsta säkerhet eller tvingas flytta till en avdelning med lägre grad av säkerhet?

Det enda vi vet med säkerhet är att rättsfallet säger att det är hyresnämnderna och Svea hovrätt (Bostadsdomstolens efterträdare) som ska avgöra den saken i enlighet med hyreslagens regler, inte politikerna i kommunens socialnämnd med hjälp av den socialrättsliga lagstiftningen.

Detta rättsfall har alltså ett högt värde som rättskälla även om det var ett obiter dictum. Domstolen kunde ha valt att låta detta bli ett av tusentals BD mål och att säga så lite som möjligt (det vill säga att hyreslagen är tillämplig och att hyresnämnden ska fatta ett hyresreglerings- 
beslut). Istället valde domstolen att lyfta fram det som ett av drygt 20 mål som varje år redovisades i RBD. Principerna för när hyreslagen är tillämplig var den ena viktiga delen och obiter dictumet som var förhållandevis konkret för vad som gäller när en hyresgäst som övertagit lägenheten blir uppsagd för att en annan behöver lägenheten bättre var den andra viktiga delen. En domstol gör inte ett så detaljerat obiter dictum i ett mål som lyfts fram på detta sätt utan att mena allvar med det.

\section{Uppsägning i samband med nedläggning av det särskilda boendet}

\section{SÖH8558-07}

Detta fall gällde en man som bott i 38 år på ett privat sjukhem i Mariannelund. Kommunen ville säga upp alla sina avtal med privata sjukhem och istället driva verksamheten i egen regi. Mannen erbjöds en lägenhet i ett servicehus i centralorten Eksjö som låg 4 mil därifrån. Uppsägningen prövades enligt $46 \S 10$ p. i hyreslagen.

Kommunen ansågs ha ett sakligt skäl att säga upp hyresavtalet. En boende på ett sjukhem kan inte kräva att verksamheten ska drivas på samma plats och på samma sätt hela tiden. Om kommunen väljer att säga upp sitt avtal med den privata omsorgsgivaren måste hyresgästen vara beredd att flytta.

Kommunen hade en plan för en mjuk övergång till det nya boendet genom att personal skulle följa med under inskolningen. Mannen hade inte gjort någon invändning mot själva omplaceringserbjudandet. Om mannen hade pekat på ett annat boende som låg närmare Mariannelund (vilket var hans hembyggd) och som kanske låg i ett samhälle av samma karaktär så hade det funnits en chans att uppsägningen underkänts. Hyresnämnden och Svea hovrätt signalerade en vilja att göra en intresseavvägning i detta mål, men de enda alternativ som stod till buds var att tvinga kommunen att fortsätta med verksamheten i Mariannelund eller att godkänna ersättningslägenheten i Eksjö och då vann kommunen.

Även SÖH 940-13 handlade om en uppsägning i samband med att ett särskilt boende lades ner. Även i det målet ville hyresgästerna inte acceptera något annat alternativ än att bo kvar och då vann kommunen.

Den hyresrättsliga situation för vanliga människor som detta är mest likt, är när ett hus ska rivas, eller kontoriseras. Huvudprincipen är då att hyresgästen måste acceptera att den gamla bostaden inte längre finns. Har hyresgästen besittningsskydd måste hyresvärden erbjuda en likvärdig ersättningslägenhet annars godkänns inte uppsägningen. ${ }^{27}$ Det verkar också vara vad man kräver av kommunen då ett särskilt boende läggs ner.

27 Jfr Edling (2014 s. 328f). Om det är balans på hyresmarknaden och hyresgästen enkelt kan hyra en annan lägenhet kan kravet på ersättningslägenhet falla bort. En överväldigande majoritet av landets hyreslägenheter finns dock på orter med bostadsbrist. 
Dessa två rättsfall har enligt mig ett lägre rättskällevärde än RBD 94:8. Rättsfallen är två av de tusentals fall som avdöms varje år och signalen om att man är beredd att göra en intresseavvägning om hyresgästen i målet tar fram en lägenhet att jämföra med var inte så viktig, detaljerad och genomtänkt, att rättsfallen lyftes fram som RH-fall.

\section{Har den som flyttar in i ett särskilt boende rätt att behålla sin gamla lägenhet?}

Hyreslagens besittningsskydd bygger på att hyresvärden som huvudregel inte får säga upp hyresgästen. Undantagen anges i 46 § och innefattar avtalsbrott från hyresgästen, att lägenheten inte finns kvar efter rivning ombyggnad och kontorisering, att hyresvärden hyr ut sin privata bostad, samt att lägenheten upplåtits som en del av ett anställningsförhållande. Sedan finns det också ett allmänt undantag kallat generalklausulen. Hyreslagens generalklausul (46 § 10 p) säger att hyresvärdens uppsägning kan godkännas om det inte strider mot god sed i hyresförhållandet och det annars inte är oskäligt mot hyresgästen att hyresförhållandet upphör.

När denna generalklausul prövas, har principerna alltid varit att en hyresgäst som använder lägenheten som sitt hem vinner. Bara den som inte använder lägenheten som ett hem riskerar att förlora. Det kan till exempel gälla övernattningslägenheter. Även studenter kan förlora sin lägenhet. Ett hyreskontrakt för en studentlägenhet är inte tänkt att gälla för livet och därför får de inte fullt besittningsskydd livet ut. ${ }^{28}$

När det gäller tillämpningen av dessa allmänna regler i förhållande till äldre är hemrätten stark. Under tiden före ädelreformen 1992 hände det att hyresgästen kunde få behålla även en subventionerad servicelägenhet om denne tvingades in på långvården. Att kunna besöka lägenheten och då liva upp gamla minnen var ett behov som hade ganska hög styrka och ibland (men inte alltid) kunde leda till att omsorgstagaren fick behålla sin gamla lägenhet trots att denne låg på långvården (Christensen 1994 s. 88f, med vidare hänvisning till Lejman 1951).

Idag är rättspraxis förmodligen lite strängare. Holmqvist \& Thomsson (2013 s. 530), redovisar några opublicerade ${ }^{29}$

28 Holmqvist \& Thomsson (2013 s. 546ff). Se också RBD 23:94 I och II. I de två fallen hade hyresgästen flyttat in i en studentlägenhet vid en tidpunkt när bostadsföretaget tillät även icke studerande att bo i sådana lägenheter. Hyresgästen hade ingen avflyttningsklausul i sitt kontrakt. Bostadsdomstolen underkände uppsägningen men sa också att de vid en senare tidpunkt nog skulle kunna godkänna den. Uppsägningar enligt denna punkt är alltså inte automatiska utan hyresnämnder och Svea hovrätt (sista instans idag) har stora möjligheter att göra avvägningar i det individuella fallet. Huvudprincipen är dock klar. Nämligen att förr eller senare så godkänner myndigheterna att en icke student blir uppsagd från en studentlägenhet. I båda fallen fick hyresgästerna en uppmaning från Bostadsdomstolen att inom en någorlunda nära framtid ordna ett annat boende.

29 Alltså rättsfall som tillhör de tusentals som inte publiceras i RH eller RBD. 
rättsfall från Svea hovrätt från tiden efter ädelreformen där den som hyr en fullgod lägenhet (och dit räknas även särskilda boenden) men behåller sin gamla vanliga lägenhet vid sidan om, inte kan behålla den gamla lägenheten om personen inte har för avsikt att återvända till lägenheten. Det räcker inte att bara vilja besöka den för att återuppliva minnen.

För den som på grund av ett omsorgsbehov flyttat till ett särskilt boende men vill behålla sin gamla lägenhet och har som mål att återvända dit, är dagens prövningar däremot generösa. Lagstiftaren vill att den personen själv ska inse det omöjliga i att komma tillbaka hem och släppa den gamla lägenheten frivilligt. Så länge den omsorgsbehövande kämpar för att återvända till sin gamla lägenhet är huvudprincipen att hon eller han behåller den (se exempelvis SÖH 602-10).

Det är även viktigt hur länge hyresgästen bott i lägenheten denne vill behålla. I SÖH 2979/09 hade en 26-årig kvinna med omsorgsbehov fått en vanlig lägenhet i Stockholm tillsammans med ett beslut om 20 timmar hjälp i boendet. Det beslutet verkställdes aldrig och efter 10 månader tvingades kvinnan lämna lägenheten och hamnade då på ett särskilt boende i Dalarna. När målet avgjordes hade hon inte bott i lägenheten på 8 år och hade inga konkreta planer på att återvända dit i närtid. Hon hade dock en förhoppning om att i framtiden studera i Stockholm och då använda lägenheten. Uppsägningen godkändes av Svea hovrätt.

\section{Varför finns så många områden där rättsfall saknas?}

En fråga som jag som jurist ställer mig är varför så många delar av hyreslagstiftningen inte blivit föremål för domar. Den frågan är jag egentligen inte tränad att svara på. En förklaring kan emellertid vara att (särskilt då det gäller äldre), de som hamnar på särskilda boenden är riktigt skröpliga.

Det är naturligtvis svårt att kategorisera människor i olika boendeformer, särskilt som lagstiftarens önskemål är att de ska kunna välja boendeform själva. Trydegård (1998 s.14) gör ändå ett försök där hon menar att den typiska äldre person som får hjälp i sitt gamla hem är en kvinna över 80 år som har problem med IADLfunktioner (Instrumental Activities of Daily Living). Det är funktioner som inte är nödvändiga för att överleva men som ger en människa möjligheter att leva självständigt i ett samhälle, att kunna laga mat, tvätta och städa är exempel på sådana aktiviteter. De här människorna bor alltså kvar i sina villor, bostadsrätter och hyreslägenheter. Den hjälp de behöver kan ges på bestämda tider enligt ett schema.

I de särskilda boendeformerna hamnar enligt Trydegård de som har problem med sina ADL-funktioner. Det är de dagliga aktiviteter som behövs för att överleva (äta, bada eller duscha, gå på toaletten m.m.). De är alltså människor som behöver mycket stöd och ibland med kort varsel. För dessa människor är rätten till ett hem något helt annat än för vanliga friska personer. Att kunna bada eller duscha mer än en gång per vecka, att kunna göra det 
utom schemat för att man just denna dag känner sig svettig är exempel på vad de vill ha för att känna att deras boende är ett hem och inte en institution.

Det finns studier som visar att äldre par vill vara tillsammans så länge omsorgsbehovet är måttligt. Då kan även den friska personen hjälpa sin partner och man stannar kvar i sin gamla bostad. När vårdbehovet blir för stort väljer man en särskild boendeform t.ex. ett sjukhem (se exempelvis Edström \& Gustafsson 2011 s. 12). Hela poängen med flytten till sjukhemmet kan vara att partnern inte längre orkar vara den som ska hjälpa till vid toalettbesöken osv. Det kan vara lättare att flytta det ansvaret till personalen på det särskilda boendet om partnern bor någon annanstans och bara hälsar på. Det kan alltså vara besvärligt att vara sammanboende i ett särskilt boende. De flesta människor har en spärr mot att ringa på personalen och be om hjälp utöver vad som är överenskommet. Har man en frisk person inneboende är det dock enkelt att be denne om hjälp med stort och smått. Det kan vara en viktig anledning till att såväl partnern som vännen, barnet eller barnbarnet inte vill bo hos den gamle utan hellre löser sina bostadsproblem på ett annat sätt. Bara om den omsorgsbehövande får så stor hjälp av personalen att den anhörige slipper höra saker som att "jag har fyra dagar kvar till nästa duschdag och känner mig svettig, snälla kan du inte hjälpa mig?" - kommer anhöriga att vilja dela en lägenhet med omsorgsbehövande personer i stor skala.

\section{Analys och diskussion av hyreslagens tillämpning $i$ särskilda boenden}

Före ädelreformen var hyreslagen i regel inte tillämplig på det som efter reformen kom att kallas särskilda boenden. Man behövde bara förstå situationen utifrån den socialrättsliga lagstiftningen.

En av de grundläggande tankarna i ädelreformen var att alla skulle få bättre hjälp att få behålla sina hem. Ville omsorgstagaren bo kvar i sin gamla bostad skulle samhället göra stora ansträngningar för att genom anpassning av lägenheten nå dit. I det sammanhanget är det märkligt att man inte ändrade hyreslagen så att hyresvärden blev skyldig att tåla de anpassningar av en lägenhet som behövs för att tillgodose en människa med omsorgsbehov, särskilt om biståndsbeslutet är så långtgående att hyresvärden också får full ersättning för att återställa huset eller lägenheten när den omsorgsbehövande har avlidit eller flyttar.

Bristande hyresbetalning borde inte förekomma som uppsägningsgrund för den som på grund av förstadier till demens inte själv kan klara av att betala sin hyra. Har socialnämnden gjort fel borde det inte påverka hyresgästens rätt att behålla sin lägenhet. Hyresvärden kan få ersättning genom skadestånd från kommunen. Vi har idag en viktig debatt runt vräkningar av barn. I de fallen drabbas barnen av att deras vårdnadshavare använt sina pengar på annat än hyran. Oavsett vad man tycker om den avvägningen kan man i alla fall förstå att samhället önskar att vårdnadshavaren ska drabbas av kon- 
sekvenser när denne inte betalar sin hyra. Enligt min mening är den som börjar bli dement lika skyddsvärd som barnet. Skillnaden är att hemlösheten i demensfallen inte kan sägas straffa någon som bör hållas ansvarig för sina felaktiga handlingar.

Osäkerheten är stor när det gäller inrymmanderätten, övertaganderätten och rätten att behålla lägenheten $i$ en efterföljande besittningsskyddstvist där den som övertagit det särskilda boendet saknar ett biståndsbeslut och hyresvärden vill säga upp denne för att ge det särskilda boendet till någon som har ett biståndsbeslut. Utöver det som tas upp i denna artikel om osäkerheter relaterade till hyreslagen är osäkerheten kring själva sambobegreppet som Ryrstedt beskriver i detta temanummer ytterligare ett viktigt skäl som talar för en specialreglering. Min bedömning är att starka skäl talar för att specialreglera hyresförhållandet i särskilda boenden. Det finns mycket som behöver ändras eller klargöras.

De tre områden som verkar minst problemfyllda är hyresregleringsfallen, störningsfallen och uppsägning i samband med att ett särskilt boende läggs ned. Men när det gäller hyresregleringsfallen ska man komma ihåg att den som bor i ett särskilt boende har två regleringar av sin avgift. En reglering enligt hyreslagen och en annan reglering enligt sociallagstiftningen. ${ }^{30} \mathrm{Gör}$ man en specialreglering av särskilda boenden, kan kanske dessa regleringar slås ihop så att en och samma myndighet prövar

30 Se Peterson-Björkdahl (2005/06) för en beskrivning av hur förvaltningsdomstolarna hanterar sociallagstiftningen i hyresfallen. alla aspekter av prissättningen/avgiftssättningen och ingenting hindrar ju att man låter de minst problemfyllda fallen $\mathrm{i}$ övrigt fungera som idag.

Vad var det egentligen som var meningen när man 1992 genomförde ädelreformen och skapade särskilda boenden som skulle falla under hyreslagstiftningen? Vilka rättigheter skulle det ge de boende som de förut inte hade? Den största rädslan för den som flyttar in i ett särskilt boende är nog rädslan för att bli isolerad från sina gamla vänner och inte kunna skaffa sig nya (se Edström \& Gustafsson 2011 s. 12). Den rädslan kan vara bakgrunden till det som Jönsson och Harnett visar i sin artikel i detta temanummer, nämligen att såväl boende som personal i kommunala äldreboenden uppfattar en stark kollektiv dimension där de boende har ett ansvar för varandra som går betydligt längre än det som gäller mellan vanliga grannar och ger också konkreta exempel på utanförskap som inte upplevs som acceptabel.

Om andra studier också bekräftar att även de som bor i andra typer av särskilda boenden upplever ett kollektivt ansvar för varandra som är betydligt mera långtgående än det som gäller mellan vanliga grannar, är det också enligt min uppfattning något som talar för att en speciallagstiftning bör övervägas. Det ansvar som hyresgästen har i förhållande till sina grannar enligt lag bör stämma överens med det ansvar samma hyresgäster menar är naturligt $\mathrm{i}$ just deras boendeform. 


\section{Litteraturlista}

Bengtsson, B. (2013). Offentliga tjänster i ett civilrättsligt perspektiv. Stockholm: Nordstedts.

Bengtsson, B. \& Hager, R. \& Victorin, A. (2013). Hyra och annan nyttjanderätt till fast egendom 8:de upplagan. Stockholm: Nordstedts.

P Björkdahl E. (2013). Hyra av bostad och lokal. Uppsala: Iustus.

Christensen, A. (1994). Hemrätt i hyreshuset - en rättsvetenskaplig studie av bostadshyresgästens besittningsskydd. Stockholm; Juristförlaget.

Edling T. (2014) 12 kap. jordabalk "hyreslagen - En kommentar.Stockholm: Karnov.

Edström, A. \& Gustafsson, M (2011). Elderly Living in Sweden-Present solutions and future trends. Stockholm: Master thesis KTH.

Grauers, F. (2014) Nyttjanderätt - Hyra bostadsrätt, arrende och tomträtt, 14:de upplagan. Lund: Juristförlaget i Lund.

Holmkvist, L. \& Thomsson, R. (2013). Hyreslagen en kommentar 10:de upplagan. Stockholm: Nordstedts.

Larsson, N. \& Synnergren, S. \& Wahlström, C. (2014). Bostadshyresavtal i praktiken 4: de upplagan. Stockholm: Nordstedts.

Lejman, F. (1951). Rättsförhållandet mellan Hyresvärd och hyresgäst, Lund: G.W.K. Gleerup.

Lehrberg, B. (2014). Praktisk juridisk metod 7: de upplagan. Uppsala: Iusté.

Peterson-Björkdahl E. (2004/05). Offentlig reglering och civilt skydd - förhållandet mellan hyreslagen och lagen om stöd och service till vissa funktionshindrade. Juridisk tidskrift vid Stockholms universitet, ss. 249-263.
Peterson-Björkdahl E. (2005/06). Laglighetsprövning av hyressättning vid särskilt boende. Juridisk tidskrift vid Stockholms universitet, ss. 147-157.

Proposition 1974:150. Bostadspolitik.

Proposition 1990/91:14. Om ansvaret för service och vård till äldre och handikappade m.m.

Proposition 1992/93:115. Om ändringar $i$ jordabalkens hyresregler.

Proposition 1997/98:46. Ändringar i hyreslagen m.m.

Proposition 2011/12:147. Rätten att få åldras tillsammans - en fråga om skälighet, värdighet och välbefinnande i äldreomsorgen.

Proposition 2013/14:198. Bristande tillgänglighet som en form av diskriminering.

Ryrstedt, E. (1998). Bodelning och bostad - Ekonomisk självständighet eller gemenskap. Lund: Juristförlaget i Lund.

Silfverberg, G. (red.) (2013). Accepterad ojämlikhet? Stockholm: Ersta Sköndal högskola förlag.

Stenberg, S-Å., Kjellbom, P., Borg, I. \& Sonmark, K. (2011). Varför vräks barn fortfarande, Socialdepartementet dnr S2010/4139/FST.

Trydegård, G-B. (1998). Public Long Term Care in Sweden:Differences and Similarities between Home-Based and Institution-Based Care of Elderly People. Journal of Gerontological Social Work 29(4), ss.13-34. 


\section{Summary}

\section{A home or the place where care is provided? \\ How the needs of older people and persons with disabilities are met in Swedish tenancy law}

A reform in 1992 made it the duty of the municipalities to create special housing (särskilt boende) for persons with disabilities. This form of housing is to be treated as a home equal to the ordinary homes of the non-impaired. The care recipient should pay rent and be provided with the home protection embedded in the Tenancy Act. The role of the municipality as a caregiver is regulated in administrative law and if there is a conflict with the care recipient, the administrative court system deals with it.

The reform created a new role for the municipalities, namely, that of the landlord. If the conflict between the caretaker and the municipalities relates to the tenant-landlord relationship it must in most cases be dealt with by rental boards and appealed against within the civil law court system.

This article describes the legal practice concerning special housing under the Tenancy Act. With regard to rent regulation, the care recipient has sometimes been successful and obtained reduced rents. Many parts of the Tenancy Act, however, contain no case law on special housing. The reason for this may be that the persons who receive special housing are so disabled that they need other things in order to get a true home compared to non-disabled persons. If the protection of the Tenancy Act and the principle of equal treatment do not meet this group's need for a home, the question should be asked whether separate legislation for special housing would be a more adequate solution to the problems this group faces. 